\title{
ethic@ \\ THE ARROGANT EYE AND THE FRENCH \\ PROHIBITIONS OF THE VEIL
}

\author{
DANIEL RESTREPO ${ }^{1}$
}

(St. John's University/USA)

\begin{abstract}
Evânia Reich presents the argument that the veil laws in France - the banning of the full-face coverings in public and the banning of the headscarf in public schools - are consistent with the emancipatory project of French Laïcité. According to this argument, the veils that Muslim women wear are symbols of their oppression, whereas French education seeks to liberate each individual and Laïcité serves as a bulwark against the creeping oppressive influence of religion. Unveiling Muslim women, then, is an act of emancipation. In this essay, I argue that the view of French secularism as an emancipatory project to free women of the oppressive mechanism of the veil is an example of what Marilyn Frye calls the "arrogant eye." In this essay, I offer an alternative approach on the veil following Frye's notion of the "loving eye."
\end{abstract}

Key Words: French Secularity; feminism; Muslim veil

"Especially after attacks in Paris by Islamists in 1995, the building of mosques was opposed by some local citizen groups, who defined these houses of religion as enemy encampments. Instances of domestic violence among Arabs became proof of the entire community's - the culture's dysfunction (while similar actions committed in 'French' households were treated as individual pathologies). Disruptions in schools were deemed acts of provocation, and difficult schools in immigrant neighborhoods were referred to by some teachers as 'lost territories' which must be retaken." Joan Wallach Scott, Politics of the Veil

\section{Introduction:}

As I write this, full-face coverings are illegal in six Western nation-states (Austria, Belgium, Bulgaria, Denmark, France, and the Netherlands), parts of four others (Germany, Italy, Spain, Switzerland), and the Canadian province of Quebec. Similar national bans have been either debated or suggested by politicians in Australia, Germany, and Switzerland. These laws and proposals are puzzling because they appear in liberal democracies, many of which are famously secular, and because they ultimately target very few women. In Austria, for example, there is an estimated 150 women who wear the full-face coverings, in Belgium such laws affect 300 women, and in France 2,000 women are targeted by the full-face cover law. ${ }^{2}$ While few women are targeted by the ban on full-face coverings, the ban against the hijab in public school 
in France affects significantly more people as it is a much more common article of clothing. The justification is the preservation of French secularism by not displaying conspicuous religious symbols.

In this essay, I argue that the French prohibitions on the veil in the name of secularism are examples of what Marilyn Frye calls the arrogant eye. The pretext of such a ban is that it will protect Muslim women from the dangers of Muslim men by freeing from the oppressive mechanism of the veil. I examine this argument and the history of the veil controversy in France to show the flaw in the reasons often given for such a ban, particularly the arguments in favor of the emancipation of Muslim women. Instead of being an emancipatory project, I argue that the veil laws are instances of the arrogant eye: a perception that views women as existing to fulfill male desires. In contrast, I want to offer an account of how the acceptance of multiculturalism in France could follow Frye's loving eye and perceive Muslim women (and men) as equal beings able to freely make their own choices for themselves about how they should live their lives.

\section{Saving Muslim Women in France?}

Since one usually frames the discussion as the politics of the veil in France, it is easy to forget that there are two prohibitions of veiling: the ban on public school wearing the headscarf and the ban on women wearing full-face coverings in public. Both bans are instituted based on a similar logic. According to Evânia Reich, following Cécile Laborde ${ }^{3}$ the "official republican" view is that "the state should promote forms of dignified life."4 The assumption is that veiling is a violation of a woman's dignity. With respect to full-face coverings, Reich makes this view clear when she conjectures "it is difficult to imagine that a Muslim woman who wears the burqa has the same freedom of choice that a European woman" would have dressed in anything else. ${ }^{5}$ What is implicit in these claims is that women veil themselves out of fear of the violence of Muslim men. The reasoning must be that the prohibitions would be a way for the state to spare Muslim women as best it can within institutions it controls. However, I think this claim is deeply flawed, which is what I intend to show in this section.

It is not surprising that the majority of the people affected by the ban are girls and women in public school. The project of French public education is to allow the schools to emancipate individuals from the controlling influences in their lives, especially the influence 
of the family. Presumably, the purpose of most state educational systems is to prepare children for civic life as adults in some way. It would seem that banning the veil is counter to this mission since it limits the student's ability to make choices regarding her faith. However, as Reich explains, the secular position is that the state should ban the wearing of veils in public schools because "the use of the veil by Muslim girls is a symbol of religious and female oppression, which infringes greatly on the autonomy of its bearer." are not forced to wear it by their (male) family members or community leaders. This implies that the Muslim home with a veiled daughter is a little Iran; a theocratic household where women are subject to male domination.

It is not the case that all veiled girl in public school are so because they are forced to be their male relatives. In fact, many girls and women in France veil as a form of resisting French demands of provocative feminine dress. Even though she considers this claim, Reich argues that there's a much more pressing problem: "violence against Muslim women who refuse to wear the veil." She asserts that those in favor of Laïcité are "right to emphasize the suffering and the oppression of Muslim women who are found beneath the dominion of the paternalism that makes women inferior." that it is a wide-spread structural problem within the French Muslim community.

Undoubtedly, at some level Reich is right: physical violence against women must be taken seriously and such violence is often a tool to assert female inferiority. Nevertheless, I find her claim dubious for two reasons. First, the way she introduces violence against Muslim women is structured as a dismissal of a different form of oppression. Even if we grant her claim, it does not make the other form of oppression any less oppressive; it just means that there are various forms of oppression Muslim women face. One should not simply dismiss oppression from one source because a possible worse oppression arises from a different source.

Second, her point's lack of empirical evidence makes this an assertion, not an argument. Unfortunately, this assertion rests on stereotypes about Muslim men as violently oppressive towards Muslim women. ${ }^{9}$ She does not need to elaborate on it because this stereotype is familiar and so it is plausible as a systemic problem. This claim makes the ban of the headscarf a lifeand-death problem: if Muslim girls cannot wear the headscarf to school than Muslim men will not harm them for refusing to wear the headscarf to school. In fact, it would seem as if we need the headscarf to be banned everywhere to protect the lives of Muslim women. Yet, if true, this is but a Band-Aid. It is a poor solution not only because it would mean that Muslim women 
who voluntarily wish to wear the headscarf in public would be denied this right, but also because it follows a similar reasoning as telling women to dress less provocatively to avoid becoming victims of sexual assault. Admittedly, it does not seem like a good analogy since, in the case of the headscarf, it is women who do not want to have to wear certain clothing while, in the case of sexual assault, it is women who do want to wear certain clothing. Both of these claims, however, rest on the assumption that what must be avoided is the incitement of male of violence by the clothing choices of women. While Reich is certainly not blaming women for violence done against them, she is nevertheless implying that banning the headscarf would give Muslim men less reason to commit such violent acts, otherwise why would she mention it? Yet her implicit solution undermines the emancipation she seeks. The logic of trying to minimize the incitement of men preserves the structure that women must live in fear of male anger.

I think the problem is poorly framed: that some Muslim women are victims of violence when they refuse to wear the headscarf is less indicative of the violence inherent in the religion than the acceptability of violence against women in general. Reich does acknowledge that violence against women extends beyond the scope of the French Muslim community, but this framing downplays the real extent of violence against women worldwide. According to the World Health Organization, 35\% of women worldwide have been victims of domestic abuse and intimate partners are responsible for $38 \%$ of murdered women. ${ }^{10}$ Brazil, Reich's home country, is in fact one of the most dangerous countries to be a woman. It ranks fifth in femicide globally. ${ }^{11}$ A headscarf law will not address this problem. My point is that, far from being a Muslim problem tied to headscarves, violence against women points to a deeper problem that affects women throughout the globe. Muslim men are not uniquely violent.

\section{The Shifting View of the Veil in France}

The secular position on the veil is that it is a religious symbol and an oppressive tool to further patriarchy by religious fundamentalists. Those in favor of this position would agree with the Moroccan feminist Fatima Mernissi who wrote that the headscarf is

a symbol revealing a collective fantasy of the Muslim community: to make women disappear, to eliminate them from communal life, to relegate them to an easily controllable terrain, the home, to prevent them from moving about, and to highlight their illegal position on male territory by means of a mask. ${ }^{12}$ 
This, however, was not always the French view of the veil. During colonialism, Europeans saw the veil as sexually frustrating for men since it allowed women to conceal their bodies from the male gaze. ${ }^{13}$ The frustrating part is that veiled women have control over who is permitted to see their uncovered hair or face. This sexual agency challenged the traditional power dynamics of both male and colonial domination. The French perspective of the veil shifted, however, in response to both global and local events. At the global scale, countries like Turkey and Iran were ruled by men who wanted to follow a Western model of modernization by secularizing. Part of this modernization was the banning of traditional clothing, including the headscarf. While Turkey remains somewhat secular - though the ban on the headscarf has since been repealed-Iran underwent a revolution in 1979 which resulted, among many other things, in a law requiring women to cover their hair. In establishing a theocracy and being openly hostile to Western interests, "Iran became for French observers a foil for their own republicanism," as Scott notes. ${ }^{14}$ Of course, Iran only works as a foil for France if one ignores the fact that Iranian women still had many civil liberties found in modern nation-states, such as the vote, ability to run for office, sex education, access to contraception, etc.

The pretext of the veil bans has been to help liberate Muslim women from the oppression of Muslim men yet the catalyst to the ban in schools seems to be more a concern with confronting French multiculturalism than ending the oppression of women. Scott traces the debate back to 1989 when three Muslim school girls were expelled from middle school for refusing to remove their headscarves. She notes that, not only was it the bicentennial of the French Revolution, but the climate at the time was deeply hostile to an American-style multiculturalism. ${ }^{15}$ The initial suspension was unconcerned with the reason why these girls chose to dress as they did; only that such a dress violated the principles of French secularism. In other words, preserving a particular ideal of French secularism was the goal and seems to remain the goal after the Stasi Report that recommended the ban fourteen years later.

One could argue that French liberalism is intertwined with secularism and so the preservation of one means the preservation of the other. This seems like a plausible claim to make in the $18^{\text {th }}$ century about the need to diminish the power of the church; however, it is significantly more unlikely in the $21^{\text {st }}$ century when secularism targets a minority religion. There is no doubt that the $18^{\text {th }}$ century Frenchmen who designed the constitution and the rights of man had good reason to be skeptical of the Catholic Church's influence on public life. Insisting on public secularity was viewed as a bulwark against the church in the hopes that people could live as free citizens. The point is that the church was viewed as a threat because 
of its dominant role in French society. Two problems emerge, however, when the logic of secularity turns towards the wearing of the headscarf. First, the secularization did not create a religiously-neutral state but rather a state that accommodates the very faith that it viewed as a threat. Catholicism, for better or worse, became part of French secularity and its national character. ${ }^{16}$ Second, Islam is not a dominant force in France at all comparable to Catholicism either in the $18^{\text {th }}$ century or even now. It is a religion practiced by a minority group made up mostly of descendants from the victims of French colonialism. Even if unintended, using the secularity law to punish Muslims in France today has the look of reliving the colonial power structures of old. The roles become reversed: the state becomes the oppressive force in the lives of religious people whereas Laïcité was conceived to combat religion as the oppressive force in the lives of citizens. Yet, as Laborde notes, the French view the state as benevolent and private institutions like the family as unjustly controlling the lives of individuals. ${ }^{17}$ The Stasi Report becomes the bulwark against the corruption by the family.

The focus of the Stasi Report is the potential women who would be required to wear the headscarf to school or in public. As Talal Asad notes, the report not only assumes that a secular state can determine what counts as a religious symbol-even when its religious significance is contested by that religion's practitioners-but also that the report could determine what a woman's true desires were. This raises epistemological and symmetrical problems. First, there is the problem of ascertaining a person's true desires. Secondly, even if this could be done, there is still the problem of focusing solely on one half of the issue. No attention was paid to the true desires of women who go without wearing the headscarf but would choose to wear it. ${ }^{18}$ If the stipulation is that some women are required to wear it, why not consider the women who go uncovered because they fear how others might treat them if they wore the headscarf? This could be an oversight, but I think it is clear that the report's focus is only on the women who fit into French national identity: the women who want to assimilate into the French secular state. Furthermore, the commission interviewed over 100 people but, of that, only two veiled women were interviewed publicly. Their interview was less than a week before the report was submitted and members of the commission admitted they had already decided the report's conclusions early on. ${ }^{19}$ These interviews certainly give the impression that they were done as a token gesture and mirror the exclusion of veiled feminists from the public discourse over the law after the report came out in favor of establishing a law to ban the headscarf in schools. Veiled feminists were excluded from the debate based on the assumption that their view was made in bad faith. ${ }^{20}$ Thus, the commission and the subsequent discourse 
excluded voices of veiled women in order to emancipate veiled women from their veils. This argument is not only circular-veiled women cannot make decisions about their veils because they are veiled - but also fundamentally sexist: Muslim women can only be free if their bodies are regulated by the state. Following this view, the notion that a woman would willingly be veiled is so foreign that it must be false. ${ }^{21}$ This neglect of veiled women and their own liberty to remain veiled exposes the ban as instance of the arrogant eye's inability to imagine other forms of agency.

\section{The Veil and Arrogant Eye}

I think there is a sad irony that the interpretation of the veil as being a tool of oppression fits within Marilyn Frye's notion of the arrogant eye, while the interpretation itself - and the support for the prohibition of the veil-is an example of how women can use the arrogant eye to oppress women. In this final section, I defend the argument that banning the veil on the assumption that it will liberate women is an instance of the arrogant eye. In contrast, a loving eye would promote a view that the emancipation of women must permit varying types of lives.

Alia al-Saji argues that the view that the veil promotes sexual repression among women as it hides their bodies is not only a Western colonial construct, but an example of Frye's arrogant eye. ${ }^{22}$ The arrogant eye is part of Frye's overall account of male domination and the oppression of women. She describes it alongside various other patriarchal tactics such as coercion, exploitation, oppression, and enslavement. Frye identifies male oppression within the Abrahamic religious texts; in particular, the discussion of man's dominion over the world. She argues that this notion that God gave to Adam not only a planet filled with plants and animals to use as he likes but also woman as a helper is emblematic of the arrogant eye. ${ }^{23}$ The arrogant eye is a perceptual stance that the other exists to fulfill one's own desires. María Lugones describes this phenomenon by arguing that arrogant perceivers "graft the substance" of others "to themselves." 24 This would make the victims of arrogant perception tools for the use of the arrogant perceiver rather than independent subjects. The point is that arrogant perception strips the victim of her subjecthood.

Frye claims arrogant perception allows men to break women into submission so they will better serve men. This is echoed in Lugones' first example of the arrogant eye: the treatment of servants. Lugones moves beyond this interpretation when she notes that in the US both white 
men and women use the arrogant eye against foreigners and racial minorities. Women are not simply the victim of the arrogant eye, but could also be its perpetrator. ${ }^{25}$ I think this is at play within the different prohibitions of veiling in France and elsewhere.

The argument that the veil is a device of female oppression fits within Frye's understanding of the arrogant eye. According to this view, the veil subjugates women and marks them as things belonging to men. They are required to wear it in public (where other men could see them) and if they fail to do so are subject to violent punishment. Sadly, a version of this is true of women in Iran and Saudi Arabia. In fact, in the latter, the male guardianship laws further enforce the notion of ownership since women are required to gain the permission of male relatives to do various things such as acquire a passport or get married. ${ }^{26}$ Only Iran and Saudi Arabia require women to veil and female guardianship is only practiced in Saudi Arabia. The populations of these countries combined make up 1\% of the world's Muslims. To suggest that these are widespread practices among Muslims is, at best, naiveté. Conjecturing, without evidence, that forced veiling is a widespread problem in France, and arguing that women should be prohibited from veiling falls within the structure of the arrogant eye.

Consider the claim that education serves as an emancipatory project for all students; the problem is that Muslims in particular are difficult to emancipate because they identify with their religion more so than with France. I find this claim dubious, but the particular difficulty faced with the emancipation of Muslim girls and women who veil implies that they especially lack agency. Here is where the arrogant eye manifests most clearly in the French disdain of the veil. The women who would veil themselves must do it because they are forced to do it. Frye discusses the difficulty men face with women who do not conform to their wishes. She writes,

The arrogant perceiver's expectation creates in the space about him a sort of vacuum mold into which the other is sucked and held. But the other is not sucked into his structure always, nor always without resistance. In the absence of his manipulation, the other is not organized primarily with reference to his interests. To the extent that she is not shaped to his will, does not fit the conformation he imposes, there is friction, anomaly or incoherence in his world. To the extent that he notices this incongruity, he can experience it in no other way than as something is wrong with her. ${ }^{27}$

I introduce this long passage because I think this answers the argument I addressed in the first section. There, Reich implied that women in burqas could not be as free as women in Western dress. I think this amounts to suggesting that something is wrong with these women. The French secular view holds that emancipation is gained through assimilation into the dominant French 
culture. It is assimilation that the arrogant perceiver wants of the other: she wants the other to be a part of her and her project. What the arrogant eye cannot have is for the other to exist independently. Resistance to this assimilation is a sign, to the arrogant perceiver, of malfunction. The support for the prohibition of the veil on the basis of emancipation is a particularly arrogant position because it ignores the possibility of other notions of agency, liberty and choice.

The defense of the prohibitions of the veil assumes that French secularism is a benign cultural phenomenon meant to emancipate women and bring about an egalitarian society. This is a particularly stark backdrop to the implied violent and misogynistic characterization of Islam. French secularity is established as the normal. Frye warns against this as well. Arrogant perception does not exist within a vacuum, but in "a culture which in many ways 'softens up' their victims for them." The arrogant perceiver is not a lone player but is supported by "the community at large" who determine the normal and augment that message through their control of "the material media culture and most other economic resources." 28 While Frye is describing how the imbalances of power and wealth in a society contribute to the domination of women by making them impoverished and dependent, a similar structure is at play within the politics of the veil. This is particularly true since French secularism is meant to play the role of emancipator for these girls. They are told how to dress and behave so that they fit within normal French society with no regard for their own interests and desires. Women, and men for that matter, who do not conform are viewed as suspicious or at best oppressed. It never occurs to the arrogant perceiver that this could be a conscious independent choice a person makes for herself.

In contrast to the arrogant perception, Frye offers the loving perception. This is a form of perception that views the other as neither threat nor servant, but as an independent being with her own interests. The loving perception recognizes a boundary between the perceiver and the perceived, but this opens up the opportunity for the loving eye to "look and listen and check and question." 29 This distance and these activities implies both seeing the other as a separate individual all her own and treating her with respect. This does not mean there cannot be commonalities or shared interests; instead the problem comes when one sees the other as an extension of the self. There must be two selves here: the perceiver and the perceived and both must stand on equal footing of respect. Where the arrogant eye sought to determine the other and break the other into servitude, the loving eye, by looking, listening and questioning, is open to what the other has to offer. The other is a source of newness about which the loving eye is 
encouraged to be curious and inquisitive. The loving eye abandons conquest and assimilation in favor of entering and experiencing the multiple worlds made manifest through respecting others.

What does this mean for France and its Muslims? It means listening to them and travelling to their world, as Lugones might put it. It is important to understand how veiling is not simply an indication of one's religious beliefs but also worn as a symbol of resistance against demands that Muslims assimilate to French society. French Muslims have plenty of reasons to be suspicious of assimilation since, regardless of how emancipated they become through their republican education, their job, housing, and life prospects remain limited because of their name and perceived inferiority. Many Muslims in France face discrimination by being segregated into banlieues, where they face job discrimination, higher unemployment and lower wages. $^{30}$ This is not helped by the fact that, despite making up a significant portion of France's population, they have little political power. There are few Muslims in parliament and Islamophobia is prevalent across the political spectrum. ${ }^{31}$ Lastly, French Muslims have remained marginalized while French Jews, who have historically faced anti-Semitism in Europe, have been able to integrate into the cultural tapestry of post-War France. ${ }^{32}$ Jewish integration is almost certainly a conscientious effort to correct for centuries of anti-Semitism culminating with the Holocaust, but French Muslims are descendants of people colonized by France yet they have not been the beneficiary of a similar moral correction.

As for the schools, some might argue that religion as a unifying identity for Muslims in homogenous European states - especially faced with world events that would affect people that look like themselves - was an important reason they resist assimilation into French society. ${ }^{33} \mathrm{I}$ think there is another reason to explain this phenomenon: the massification of their education. Joan Wallach Scott notes that from the late $19^{\text {th }}$ century to the mid-1960s, few schoolchildren completed secondary school. By the 1970s everyone was expected to attend the French equivalent of middle school and high school. This lead to overcrowded and underfunded schools; people with connections could avoid this fate for their children, while working class and immigrant families were stuck with local schools in their neighborhoods. Not only did there become a class stratification in the French school system, but the lessons many Muslim students took away from their education was that it was useless and helped to promote existing hierarchies. Muslim students were told they came from inferior places and this stigmatized them on the job market as employers assumed they were ill-prepared for work. Religion then becomes a unifying factor because as school massification took place so too were students told 
to express themselves. Muslim students started to find expression in visible signs of their religion. ${ }^{34}$

School as the ideal place of emancipation with its important role in social mobility is a promise not open for all. Though these are the ideals of the French educational system, they are not its realities. Muslims students are not responsible for their school's failures; they are simply responding to them. There are real and enduring structural problems that Muslims face in France. It takes time, money, and political will to fix them; but, more importantly it takes recognition of the problem in the first place. Such a recognition is only possible with the loving eye that is interested in understanding why there is resentment and resistance in the first place; the loving eye that travels within other worlds to better understand other people.

It is easier to blame religion or cultural differences for these social woes, but legislating away what the state deems to be ostentatious religious symbols does not address any of these underlying problems Muslims face in France. It simply institutionalizes the disdain for Muslims as Muslims in France. The ban on the veil did not come from Muslim girls or women, it came from people who claimed to speak for them but were interested in preserving an idealized French secularity. It is for people who effectively silence them, graft them to themselves for their purposes, and eliminate part of their agency. Muslim women in France do not need to be saved, they need to be respected; they need to be believed to have just as much agency as their Christian, Jewish or secular counterparts. Pathologizing voluntary veiling is an example of the arrogant eye, and it runs counter to any project that seeks to emancipate women.

\section{Conclusion}

The headscarf and full-face covering laws throughout Europe are iterations of the arrogant eye. They are attempts to force assimilation onto a minority group and so they are oppressive by nature. Far from emancipating women, such laws not only limit the choices women have in their everyday attire, they reinforce stereotypes by criminalizing innocuous behavior. This is particularly dangerous during these times of rising nationalism and antiMuslim sentiment in the West. Criminalizing clothing makes the wearer a deviant; someone to be looked upon with suspicion or resentment at the threat she poses to liberal society. This is not mere speculation. Recently Denmark banned full-face coverings in public. A woman was in a shopping mall wearing a niqab and, in response to this illegal action, another woman 
decided to tear it off her head. ${ }^{35}$ By codifying such laws, it normalizes disrespect towards Muslims and exposes these women to public censure and even violence. Since they should not be wearing these veils, this woman saw it as permissible to forcibly remove it from the other woman's body. People's antipathy towards Muslims wearing the veil leads them to literally rip the clothes from their bodies. I believe this is a far greater danger to the wellbeing and emancipation of women than permitting people to wear the veil if they wish. 


\section{Notes:}

${ }^{1}$ Assistant Professor in Philosophy at St. John's University, New York, N.Y., USA. E-mail: restrepo.dan@gmail.com. I would like to thank Ítalo Alves, Priscilla de Miranda, and my anonymous reviewers for their help in improving this essay.

2 "The Islamic Veil Across Europe," BBC News, May 31, 2018, http://www.bbc.com/news/world-europe13038095.

${ }^{3}$ Cécile Laborde, Critical Republicanism: The Hijab Controversy and Political Philosophy (New York: Oxford University Press, 2008), 8.

${ }^{4}$ Evânia Reich, “O Republicanismo Laico Francês e a Proibiçāo do Vēu,” Ethic@ 14, no. 2 (July 2015): 207. All quotations from Reich are my translations.

${ }^{5}$ Reich, "Republicanismo," 211.

${ }^{6}$ Reich, "Republicanismo," 207.

${ }^{7}$ Reich, "Republicanismo," 213.

${ }^{8}$ Reich, "Republicanismo," 213.

${ }^{9}$ After the US toppled the Taliban in 2001, then-First Lady Laura Bush gave a radio address regarding the war in Afghanistan a few months later. There she said, "Because of our recent military gains in much of Afghanistan, women are no longer imprisoned in their homes. They can listen to music and teach their daughters without fear of punishment. The fight against terrorism is also a fight for the rights and dignity of women." Lila Abu-Lughod argues Bush's radio address reinforces a "chasmic divides, primarily between the 'civilized people throughout the world' whose hearts break for the women and children of Afghanistan and the Taliban-and-the-terrorists, the cultural monsters who want to, as [Bush] puts it, 'impose their world on the rest of us." Abu-Lughod's point is that our image of Muslims as uncivilized, oppressive, and violent serves as a justification for the need to save Muslim women from Muslim men. Lila Abu-Lughod, "Do Muslim Women Need Saving? Anthropological Reflections on Cultural Relativism and Its Others," American Anthropologist 104, no. 3 (Sep. 2002): 784.

10 "Violence against Women," World Health Organization, November 29, 2017, https://www.who.int/newsroom/fact-sheets/detail/violence-against-women.

${ }^{11}$ Julio Jacobo Waiselfisz, Mapa da Violência 2015: Homicídio de Mulheres no Brasil (Brasilia: UNESCO Brasil, 2015), 27.

${ }^{12}$ Quoted in Laborde, Critical, 114.

${ }^{13}$ Frantz Fanon argued the veiled "woman who sees without being seen frustrates the colonizer. There is no reciprocity. She does not yield herself, does not give herself, does not offer herself." Frantz Fanon, A Dying Colonialism, trans. Haakon Chevalier (New York: Grove Press, 1965), 44.

${ }^{14}$ Scott, Politics, 70.

${ }^{15}$ Scott, Politics, 21-23.

${ }^{16}$ As Alia al-Saji writes, "French secularism was built on a history of Christianity; that it has had to accommodate and coexist with Catholicism has meant, as some commentators argue, that secular public space is not a generalized but a structured absence. Secular space in fact holds the trace of religious practices that were removed but not contradicted; in other words, this space is structured such that certain religious practices can coexist with it, even though they are no longer explicitly inscribed within it." Alia Al-Saji, "The Racialization of Muslim Veils: A Philosophical Analysis," Philosophy and Social Criticism 36, no. 8 (2010): 881.

${ }^{17}$ Laborde, Critical, 102. 
18 Talal Asad, "Trying to Understand French Secularism," in Political Theologies: Public Religions in a PostSecular World, eds. Hent de Vries and Lawrence Eugene Sullivan (New York: Fordham University Press, 2009), 500-504.

${ }^{19}$ Al-Saji, "Racialization,” footnote 93, 901-902.

${ }^{20}$ Al-Saji, "Racialization," 881. When the law did pass, al-Saji argues, it meant "freedom from gender oppression effectively overwrites freedom of conscience, broadly defined within French secularism. Implicit in the pro-law argument is the assumption that veiled women cannot be understood to have freedom of conscience, since their agency or subjectivity has been mutilated by familial or communal forms of gender oppression; they have been de-subjectified." Al-Saji, "Racialization,” 880.

${ }^{21}$ As Scott notes, this view is a crucial part of the narrative of veil ban as a form of emancipation. She writes, "to justify imposing a law on these young women, the proponents of the ban had to identify them as victims who had been denied the right to choose by an oppressive, authoritarian community." Scott, Politics, 126.

${ }^{22}$ Al-Saji, "Racialization,” 886.

23 "Man is invited to subdue the earth and have dominion over every living thing on it, all of which is said to exist 'to you' 'for meat.' Woman is created to be man's helper. This captures in myth Western Civilization's primary answer to the philosophical question of man's place in nature: everything that is is resource for man's exploitation. With this world view, men see with arrogant eye which organize everything seen with reference to themselves and their own interests." Marilyn Frye, "In and Out of Harm's Way: Arrogance and Love," in The Politics of Reality: Essays in Feminist Theory (Freedom, CA: The Crossing Press, 1983), 66-67.

${ }^{24}$ María Lugones, “Playfulness, 'World'-Travelling, and Loving Perception,” Hypatia 2, no.2 (Summer 1987): 4.

${ }^{25}$ Lugones, "Playfulness," 5-6.

${ }^{26}$ Male guardianship also existed in the West until relatively recently. As Frye notes, "In a liberal college town in the United States in the late 70s, a woman went to get a library card at the local public library. She was told she could not get it without her husband's signature; a firm policy; no, she would need no one else's signature if she were single." Frye, "In," 65. While in France, until 1975, there was a law that allowed men to chastise their wives for "insubordination." Asad, "Trying," 502.

${ }^{27}$ Frye, "In," 69.

${ }^{28}$ Frye, "In," 72, footnote.

${ }^{29}$ Frye, “In," 75.

${ }^{30}$ Barbara Franz, "Europe's Muslim Youth: An Inquiry into the Politics of Discrimination, Relative Deprivation, and Identity Formation," Mediterranean Quarterly 18, no. 1 (Winter 2007): 102-103.

${ }^{31}$ Edwy Plenel notes that future prime minister Manuel Valls, a socialist, stated three challenges for France in the next decade: "immigration, due to African demographics; the compatibility of Islam with democracy; and the problems raised by immigrant workers being joined by their families." Edwy Plenel, For the Muslims: Islamophobia in France, trans. David Fernbach (London: Verso, 2016), 34.

${ }^{32}$ Even Jews from North Africa, who behave in similar ways to Muslims, were able to integrate into French society despite the barriers that exist for Muslims from the same region. Joan Wallach Scott, The Politics of the Veil (Princeton, NJ: Princeton University Press, 2010): 77-78.

${ }^{33}$ Bhikhu Parekh, European Liberalism and the Muslim Question (Leiden: Amsterdam University Press, 2008), $8-9$.

${ }^{34}$ Scott, Politics, 108-111.

35 "First Woman Fined in Denmark for Wearing Full-Face Veil," The Guardian, August 3, 2018, https://www.theguardian.com/world/2018/aug/04/first-woman-fined-in-denmark-for-wearing-full-face-veil. 


\section{References:}

"First Woman Fined in Denmark for Wearing Full-Face Veil." The Guardian, August 3, 2018. https://www.theguardian.com/world/2018/aug/04/first-woman-fined-in-denmark-forwearing-full-face-veil.

“The Islamic Veil Across Europe." BBC News, December 6, 2016. http://www.bbc.com/news/world-europe-13038095.

"Violence against Women." World Health Organization, November 29, 2017. https://www.who.int/news-room/fact-sheets/detail/violence-against-women.

Abu-Lughod, Lila. "Do Muslim Women Need Saving? Anthropological Reflections on Cultural Relativism and Its Others." American Anthropologist 104, no. 3 (Sep. 2002): 783790.

Al-Saji, Alia. "The Racialization of Muslim Veils: A Philosophical Analysis." Philosophy and Social Criticism 36, no. 8 (2010): 875-902.

Asad, Talal. "Trying to Understand French Secularism." In Political Theologies: Public Religions in a Post-Secular World, edited by Hent de Vries and Lawrence Eugene Sullivan, 494-527. New York: Fordham University Press, 2009.

Fanon, Frantz. A Dying Colonialism. Translated by Haakon Chevalier. New York: Grove Press, 1965.

Franz, Barbara. "Europe's Muslim Youth: An Inquiry into the Politics of Discrimination, Relative Deprivation, and Identity Formation." Mediterranean Quarterly 18, no. 1 (Winter 2007): 89-112.

Frye, Marilyn. "In and Out of Harm's Way: Arrogance and Love." In The Politics of Reality: Essays in Feminist Theory, 52-83. Freedom, CA: The Crossing Press, 1983.

Laborde, Cécile. Critical Republicanism: The Hijab Controversy and Political Philosophy. New York: Oxford University Press, 2008.

Lugones, María. "Playfulness, 'World'-Travelling, and Loving Perception.” Hypatia 2, no.2 (Summer 1987): 3-19.

Parekh, Bhikhu. European Liberalism and the Muslim Question. Leiden: Amsterdam University Press, 2008.

Plenel, Edwy. For the Muslims: Islamophobia in France. Translated by David Fernbach. London: Verso, 2016.

Reich, Evânia. “O Republicanismo Laico Francês e a Proibição do Véu.” Ethic@ 14, no. 2 (July 2015): 199-221. 
Scott, Joan Wallach. The Politics of the Veil. Princeton, NJ: Princeton University Press, 2010.

Waiselfisz, Julio Jacobo. Mapa da Violência 2015: Homicídio de Mulheres no Brasil. Brasilia: UNESCO Brasil, 2015. 